\title{
Synthesis and Side-Chain Crystallization of New Comb-Like Polymers from 2-Amino-4-( $N$-alkylanilino)-6-isopropenyl-1,3,5-triazines
}

\author{
Hideo Kunisada, Yasuo YuKi, Shuji Kondo, \\ Jun Mryatake, and Chieko MaEDA \\ Department of Materials Science and Enginnering, \\ Nagoya Institute of Technology, Gokiso-cho, \\ Showa-ku, Nagoya 466, Japan
}

(Received September 4, 1989)

\begin{abstract}
New isopropenyl-1,3,5-triazines, e.g., 2-amino-4-( $N$-propyl(N3), hexyl(N6), octyl(N8), decyl(N10), dodecyl(N12), tetradecyl(N14), hexadecyl(N16), octadecyl(N18), and decosyl(N22)anilino)-6-isopropenyl-1,3,5-triazine, were prepared by the reaction of 2-amino-4anilino-6-isopropenyl-1,3,5-triazine with corresponding alkyl bromides in the presence of sodium hydride in dimethyl sulfoxide. The alkylation reaction proceeded selectively on the imino group, and the products were obtained in high yields. Polymerizations of these monomers were carried out using azobisisobutyronitrile as an initiator. Glass transition temperature of the polymers decreased with increasing the numbers of carbon atoms in alkyl side-chain. The crystallization of the alkyl side-chains in the comb-like polymers was investigated by differential scanning calorimetry (DSC). The crystallization exothermic and the melting endothermic peaks based on the side-chains of the polymers containing long alkyl groups in excess of 14 carbon atoms were observed in DSC thermograms.
\end{abstract}

KEY WORDS Isopropenyl-1,3,5-triazines / Alkylation Reaction / Glass Transition Temperature / Comb-Like Polymer / Side-Chain Crystallization /

Since the polymerization of $n$-alkyl acrylates were reported by Rehberg and Fisher, ${ }^{1}$ a lot of articles have been published concerning the syntheses, structure, properties, and applications of the polymers having long alkyl side-chains, so-called comb-like polymers. Kaufman et $a .^{2}$ found that alkyl groups of poly(n-alkyl acrylates) undergo side-chain crystallization. Wiley et al. ${ }^{3}$ and Rogers et al. ${ }^{4}$ reported the relationships between the glass transition temperature $\left(T_{\mathrm{g}}\right)$ and the length of alkyl groups of poly( $n$-alkyl methacrylate). Subsequently, many studies on the $T_{\mathrm{g}}$, the crystallization of side-chains, and the mechanical properties were reported for $\operatorname{poly}(p-n$ alkylstyrenes $){ }^{5}$ poly( $n$-alkyl vinyl ethers $),{ }^{6}$ poly $(N$ - $n$-alkylmaleimides $),{ }^{7}$ poly $(n$-alkyl itaconates $),{ }^{8}$ and $\operatorname{poly}(N$ - $n$-alkylacrylamides $){ }^{9}$ Yokota et al. ${ }^{10-13}$ investigated the synthsis, structure, and thermal properties of widelyspaced comb-like polymers. In addition, polymerized Langmuir-Blodgett (LB) film was obtained by the polymerization of $\mathrm{N}$-octadecylacrylamide in LB multilayers. ${ }^{14}$

Comb-like polymers having rigid backbone as well were reported. For example, Takayanagi et $a l .{ }^{15,16}$ found that $N$-alkylated $\operatorname{poly}(p$ phenylene terephthalamide), prepared by polymer reaction, exhibit good solubility, thermoplastic processability, peculiar mechanical properties and ability of liquid crystal formation.

We have been investigated the synthesis and polymerization of isopropenyl-1,3,5-triazines, ${ }^{17-19}$ and found that the polymers are one of the highest $T_{\mathrm{g}}$ and best thermal stability among vinyl polymers so-far studied owing to the rigidity and the hydrogen bond- 
ing of amino group. Therefore, introduction of the flexible alkyl side-chains into these polymers is of interest in thermal properties and mechanical properties. In this paper, we describe the synthesis and polymerization of 2-amino-4-( $N$ - $n$-alkylanilino)-6-isopropenyl1,3,5-triazines, and discuss the crystallization of alkyl side-chains of the obtained polymers.

\section{EXPERIMENTAL}

\section{Materials}

Dimethyl sulfoxide (DMSO), $N, N$-dimethylacetamide (DMAc), tetrahydrofuran (THF), and benzene were purified by the ordinary methods and distilled over calcium hydride under nitrogen. Sodium hydride as a suspension in paraffin and alkyl bromides were reagent grade and were used as received. 2-Amino-4-anilino-6-isopropenyl-1,3,5-triazine (AAIT) was prepared as described in the previous paper. ${ }^{17}$

\section{Measurements}

Nuclear magnetic resonance (NMR) spectroscopy was done in perdeuteriodimethyl sulfoxide (DMSO- $d_{6}$ ) or deuteriochloroform solutions on a Hitachi R-600 spectrometer operated at $60 \mathrm{MHz} . T_{\mathrm{g}}$ and $\mathrm{mp}$ were determined by differential scanning calorimetry (DSC) on a Rigaku-Denki DSC-8230 at the heating rate $20^{\circ} \mathrm{C} \mathrm{min}^{-1}$. DSC at low temperature was carried out from -100 to $100^{\circ} \mathrm{C}$ on a Rigaku-Denki Thermoflex with a low temperature unit at the heating and cooling rates of $10^{\circ} \mathrm{Cmin}^{-1}$. Molecular weight of polymers were determined by gel-permeation chromatography (GPC) on a TOSOH HLC803D with $\mathrm{G} 2000 \mathrm{H}, \mathrm{G} 3000 \mathrm{H}$, and $\mathrm{G} 5000 \mathrm{H}$ TSK gel-columns and a differential refractometric detector in THF. The columns were calibrated with a set of monodisperse polystyrene standards.

\section{Monomers}

2-Amino-4-( $N$-propylanilino)-6-isopropenyl-1,3,5-triazine (N3). AAIT $(22.7 \mathrm{~g}, 0.1 \mathrm{~mol})$ was added to dimethyl sulfoxide $(300 \mathrm{ml})$ in the presence of sodium hydride $(60 \%$ suspension in paraffin) $(4.0 \mathrm{~g}, 0.1 \mathrm{~mol})$ with stirring, and stirring was continued at $30^{\circ} \mathrm{C}$ for $2 \mathrm{~h}$. Then, propyl bromide $(12.3 \mathrm{~g}, 0.1 \mathrm{~mol})$ was added dropwise and the mixture was stirred at $30^{\circ} \mathrm{C}$ for $24 \mathrm{~h}$. The reaction mixture was poured into a large excess of water to precipitate the solid. The solid was filtered, and washed several times with water. The product was recrystallized four times from methanol. ${ }^{1} \mathrm{H}$ NMR (DMSO- $d_{6}$ ), $\delta 0.88\left(\mathrm{t}, 3 \mathrm{H}, \mathrm{CH}_{3}\right), 1.67\left(\mathrm{~m}, 2 \mathrm{H}, \mathrm{CH}_{2}\right), 1.98$ (s, 3H, $\left.\mathrm{CH}_{3}\right), 3.93\left(\mathrm{t}, 2 \mathrm{H}, \mathrm{CH}_{2}\right), 5.41(\mathrm{br} \mathrm{s}, 1 \mathrm{H}$, $\mathrm{CH}), 6.23$ (brs, $1 \mathrm{H}, \mathrm{CH}), 6.76\left(\mathrm{~s}, 2 \mathrm{H}, \mathrm{NH}_{2}\right.$ ), $7.38 \mathrm{ppm}\left(\mathrm{s}, 5 \mathrm{H}, \mathrm{C}_{6} \mathrm{H}_{5}\right)$.

2-Amino-4-( $N$-hexylanilino)-6-isopropenyl1,3,5-triazine (N6). N6 was synthesized by the reaction of AAIT with hexyl bromide similarly to the synthesis of N3. The product was recrystallized three times from $n$-hexane. ${ }^{1} \mathrm{H}$ NMR (DMSO- $\left.d_{6}\right), \delta 0.84\left(\mathrm{t}, 3 \mathrm{H}, \mathrm{CH}_{3}\right), 1.26$ $\left(\mathrm{m}, 8 \mathrm{H}, \mathrm{C}_{4} \mathrm{H}_{8}\right), 1.98\left(\mathrm{~s}, 3 \mathrm{H}, \mathrm{CH}_{3}\right), 3.93(\mathrm{t}, 2 \mathrm{H}$, $\mathrm{CH}_{3}$ ), 5.40 (br s, $\left.1 \mathrm{H}, \mathrm{CH}\right), 6.20$ (br s, $\left.1 \mathrm{H}, \mathrm{CH}\right)$, $6.68\left(\mathrm{~s}, 2 \mathrm{H}, \mathrm{NH}_{2}\right), 7.30 \mathrm{ppm}\left(\mathrm{s}, 5 \mathrm{H}, \mathrm{C}_{6} \mathrm{H}_{5}\right)$.

2-Amino-4-( $N$-octylanilino)-6-isopropenyl1,3,5-triazine (N8). N8 was synthesized by the reaction of AAIT with octyl bromide similarly to the synthesis of N3. The product was recrystallized three times from $n$-hexane. ${ }^{1} \mathrm{H}$ NMR (DMSO- $\left.d_{6}\right), \delta 0.84\left(\mathrm{t}, 3 \mathrm{H}, \mathrm{CH}_{3}\right), 1.22$ $\left(\mathrm{m}, 12 \mathrm{H}, \mathrm{C}_{6} \mathrm{H}_{12}\right), 1.98\left(\mathrm{~s}, 3 \mathrm{H}, \mathrm{CH}_{3}\right), 3.94(\mathrm{t}$, $2 \mathrm{H}, \mathrm{CH}_{2}$ ), 5.40 (br s, $1 \mathrm{H}, \mathrm{CH}$ ), 6.20 (br s, $1 \mathrm{H}$, $\mathrm{CH}), 6.68\left(\mathrm{~s}, 2 \mathrm{H}, \mathrm{NH}_{2}\right), 7.30 \mathrm{ppm}(\mathrm{s}, 5 \mathrm{H}$, $\mathrm{C}_{6} \mathrm{H}_{5}$ ).

2-Amino-4-( $N$-decylanilino)-6-isopropenyl1,3,5-triazine (N10). N10 was synthesized by the reaction of AAIT with decyl bromide similarly to the synthesis of N3. The product was recrystallized three times from $n$-hexane. ${ }^{1} \mathrm{H}$ NMR (DMSO- $\left.d_{6}\right), \delta 0.86\left(\mathrm{t}, 3 \mathrm{H}, \mathrm{CH}_{3}\right)$, $1.24\left(\mathrm{~m}, 16 \mathrm{H}, \mathrm{C}_{8} \mathrm{H}_{16}\right), 1.98\left(\mathrm{~s}, 3 \mathrm{H}, \mathrm{CH}_{3}\right), 3.95$ (t, 2H, $\mathrm{CH}_{2}$ ), 5.40 (brs, 1H, CH), 6.21 (br s, $1 \mathrm{H}, \mathrm{CH}), 6.68$ (s, 2H, $\left.\mathrm{NH}_{2}\right), 7.30 \mathrm{ppm}(\mathrm{s}, 5 \mathrm{H}$, 
$\mathrm{C}_{6} \mathrm{H}_{5}$ ).

2-Amino-4-( $N$-dodecylanilino)-6-isopropenyl-1,3,5-triazine (N12). N12 was synthesized by the reaction of AAIT with dodecyl bromide similarly to the synthesis of N3. The product was recrystallized three times from methanol. ${ }^{1} \mathrm{H}$ NMR (DMSO- $\left.d_{6}\right), \delta 0.82\left(\mathrm{t}, 3 \mathrm{H}, \mathrm{CH}_{3}\right.$ ), $1.21\left(\mathrm{~m}, 20 \mathrm{H}, \mathrm{C}_{10} \mathrm{H}_{20}\right), 1.96\left(\mathrm{~s}, 3 \mathrm{H}, \mathrm{CH}_{3}\right), 3.94$ (t, 2H, $\mathrm{CH}_{2}$ ), 5.40 (br s, 1H, CH), 6.25 (brs, $1 \mathrm{H}, \mathrm{CH}), 6.68\left(\mathrm{~s}, 2 \mathrm{H}, \mathrm{NH}_{2}\right), 7.30 \mathrm{ppm}(\mathrm{s}, 5 \mathrm{H}$, $\mathrm{C}_{6} \mathrm{H}_{5}$ ).

2-Amino-4-( $N$-tetradecylanilino)-6-isopropenyl-1,3,5-triazine (N14). N14 was synthesized by the reaction of AAIT with tetradecyl bromide similarly to the synthesis of N3. The product was recrystallized from $n$-hexane, and further recrystallized three times from methanol. ${ }^{1} \mathrm{H}$ NMR (DMSO- $\left.d_{6}\right), \delta 0.84\left(\mathrm{t}, 3 \mathrm{H}, \mathrm{CH}_{3}\right.$ ), $1.22\left(\mathrm{~m}, 24 \mathrm{H}, \mathrm{C}_{12} \mathrm{H}_{24}\right), 1.96\left(\mathrm{~s}, 3 \mathrm{H}, \mathrm{CH}_{3}\right), 3.92$ (t, 2H, $\mathrm{CH}_{2}$ ), 5.40 (br s, 1H, CH), 6.24 (br s, $1 \mathrm{H}, \mathrm{CH}), 6.68$ (s, 2H, $\left.\mathrm{NH}_{2}\right), 7.30 \mathrm{ppm}(\mathrm{s}, 5 \mathrm{H}$, $\mathrm{C}_{6} \mathrm{H}_{5}$ ).

2-Amino-4-( $N$-hexadecylanilino)-6-isopropenyl-1,3,5-triazine (N16). N16 was synthesized by the reaction of AAIT with hexadecyl bromide similarly to the synthesis of N3. The product was recrystallized in a similar manner as N14. ${ }^{1} \mathrm{H}$ NMR (DMSO- $\left.d_{6}\right), \delta 0.82(\mathrm{t}, 3 \mathrm{H}$, $\left.\mathrm{CH}_{3}\right), 1.20\left(\mathrm{~m}, 28 \mathrm{H}, \mathrm{C}_{14} \mathrm{H}_{28}\right), 1.96(\mathrm{~s}, 3 \mathrm{H}$, $\mathrm{CH}_{3}$ ), 3.92 (t, $2 \mathrm{H}, \mathrm{CH}_{2}$ ), 5.38 (br s, $\left.1 \mathrm{H}, \mathrm{CH}\right)$, 6.25 (brs, $1 \mathrm{H}, \mathrm{CH}), 6.65\left(\mathrm{~s}, 2 \mathrm{H}, \mathrm{NH}_{2}\right)$, $7.29 \mathrm{ppm}\left(\mathrm{s}, 5 \mathrm{H}, \mathrm{C}_{6} \mathrm{H}_{5}\right)$.

2-Amino-4-( $N$-octadecylanilino)-6-isopropenyl-1,3,5-triazine (N18). N18 was synthesized by the reaction of AAIT with octadecyl bromide similarly to the synthesis of N3. The product was recrystallized in a similar manner as $\mathrm{N} 14 .{ }^{1} \mathrm{H} \mathrm{NMR}\left(\mathrm{CDCl}_{3}\right), \delta 0.88\left(\mathrm{t}, 3 \mathrm{H}, \mathrm{CH}_{3}\right)$, $1.24\left(\mathrm{~m}, 32 \mathrm{H}, \mathrm{C}_{16} \mathrm{H}_{32}\right), 2.03\left(\mathrm{~s}, 3 \mathrm{H}, \mathrm{CH}_{3}\right), 3.96$ (t, $2 \mathrm{H}, \mathrm{CH}_{2}$ ), 5.38 (br s, $3 \mathrm{H}, \mathrm{CH}+\mathrm{NH}_{2}$ ), 6.28 (br s, $1 \mathrm{H}, \mathrm{CH}), 7.29 \mathrm{ppm}\left(\mathrm{s}, 5 \mathrm{H}, \mathrm{C}_{6} \mathrm{H}_{5}\right)$.

2-Amino-4-( $N$-docosylanilino)-6-isopropenyl-1,3,5-triazine (N22). N22 was synthesized by the reaction of AAIT with docosyl bromide similarly to the synthesis of N3. The product was recrystallized three times from $n$-hexane. ${ }^{1} \mathrm{H}$ NMR $\left(\mathrm{CDCl}_{3}\right), \delta 0.87\left(\mathrm{t}, 3 \mathrm{H}, \mathrm{CH}_{3}\right), 1.23$ $\left(\mathrm{m}, 40 \mathrm{H}, \mathrm{C}_{20} \mathrm{H}_{40}\right), 2.03\left(\mathrm{~s}, 3 \mathrm{H}, \mathrm{CH}_{3}\right), 3.96(\mathrm{t}$, $\left.2 \mathrm{H}, \mathrm{CH}_{2}\right), 5.16\left(\mathrm{~s}, 2 \mathrm{H}, \mathrm{NH}_{2}\right), 5.42(\mathrm{br} \mathrm{s}, 1 \mathrm{H}$, $\mathrm{CH}), 6.30$ (brs, $1 \mathrm{H}, \mathrm{CH}), 7.32 \mathrm{ppm}(\mathrm{s}, 5 \mathrm{H}$,

Table I. Synthesis of 2-amino-4-( $N$-alkylanilino)-6-isopropenyl-1,3,5-triazines

\begin{tabular}{|c|c|c|c|c|c|c|c|}
\hline \multirow{2}{*}{ Monomer } & \multirow{2}{*}{$\mathrm{R}$} & \multirow{2}{*}{$\frac{\text { Yield }}{\%}$} & \multirow{2}{*}{$\frac{\mathrm{mp}}{{ }^{\circ} \mathrm{C}}$} & \multicolumn{4}{|c|}{ Elemental analysis (calcd) } \\
\hline & & & & $\mathrm{C} \%$ & $\mathrm{H} \%$ & N\% & \\
\hline \multirow[t]{2}{*}{ N3 } & \multirow{2}{*}{$n-\mathrm{C}_{3} \mathrm{H}_{7}$} & \multirow[t]{2}{*}{91.7} & \multirow[t]{2}{*}{107} & 66.69 & 7.21 & 25.90 & \\
\hline & & & & $(66.89$ & 7.11 & 26.00 & $\left.; \mathrm{C}_{15} \mathrm{H}_{19} \mathrm{~N}_{5}\right)$ \\
\hline \multirow[t]{2}{*}{ N6 } & \multirow[t]{2}{*}{$n-\mathrm{C}_{6} \mathrm{H}_{13}$} & \multirow[t]{2}{*}{97.3} & \multirow[t]{2}{*}{68} & 69.06 & 8.06 & 22.39 & \\
\hline & & & & $(69.42$ & 8.09 & 22.48 & $\left.; \mathrm{C}_{18} \mathrm{H}_{25} \mathrm{~N}_{5}\right)$ \\
\hline \multirow{2}{*}{ N8 } & \multirow{2}{*}{$n-\mathrm{C}_{8} \mathrm{H}_{17}$} & \multirow[t]{2}{*}{98.1} & \multirow[t]{2}{*}{62} & 70.95 & 8.62 & 20.76 & \\
\hline & & & & $(70.76$ & 8.61 & 20.63 & $\left.; \mathrm{C}_{20} \mathrm{H}_{29} \mathrm{~N}_{5}\right)$ \\
\hline \multirow{2}{*}{ N10 } & \multirow{2}{*}{$n-\mathrm{C}_{10} \mathrm{H}_{21}$} & \multirow[t]{2}{*}{97.9} & \multirow[t]{2}{*}{68} & 71.98 & 8.79 & 18.99 & \\
\hline & & & & $(71.90$ & 9.05 & 19.05 & $; \mathrm{C}_{22} \mathrm{H}_{33} \mathrm{~N}_{5}$ ) \\
\hline \multirow[t]{2}{*}{ N12 } & \multirow{2}{*}{$n-\mathrm{C}_{12} \mathrm{H}_{25}$} & \multirow[t]{2}{*}{99.8} & \multirow[t]{2}{*}{63} & 72.63 & 9.52 & 17.70 & \\
\hline & & & & $(72.87$ & 9.43 & 17.70 & $; \mathrm{C}_{24} \mathrm{H}_{37} \mathrm{~N}_{5}$ ) \\
\hline \multirow[t]{2}{*}{ N14 } & \multirow{2}{*}{$n-\mathrm{C}_{14} \mathrm{H}_{29}$} & \multirow[t]{2}{*}{92.5} & \multirow[t]{2}{*}{64} & 74.01 & 9.96 & 16.03 & \\
\hline & & & & $(73.71$ & 9.75 & 16.53 & $; \mathrm{C}_{26} \mathrm{H}_{41} \mathrm{~N}_{5}$ ) \\
\hline \multirow[t]{2}{*}{ N16 } & \multirow{2}{*}{$n-\mathrm{C}_{16} \mathrm{H}_{33}$} & \multirow[t]{2}{*}{94.5} & \multirow[t]{2}{*}{68} & 74.43 & 10.19 & 15.33 & \\
\hline & & & & $(74.45$ & 10.04 & 15.50 & $; \mathrm{C}_{28} \mathrm{H}_{45} \mathrm{~N}_{5}$ ) \\
\hline \multirow[t]{2}{*}{ N18 } & \multirow{2}{*}{$n-\mathrm{C}_{18} \mathrm{H}_{37}$} & 98.4 & 72 & 75.28 & 10.44 & 14.59 & \\
\hline & & & & $(75.11$ & 10.29 & 14.60 & $\left.; \mathrm{C}_{30} \mathrm{H}_{49} \mathrm{~N}_{5}\right)$ \\
\hline $\mathrm{N} 22$ & $n-\mathrm{C}_{22} \mathrm{H}_{45}$ & 98.1 & 80 & 76.03 & 11.07 & 12.90 & \\
\hline & & & & $(75.63$ & 11.07 & 13.04 & $\left.; \mathrm{C}_{34} \mathrm{H}_{57} \mathrm{~N}_{5}\right)$ \\
\hline
\end{tabular}


$\mathrm{C}_{6} \mathrm{H}_{5}$ ).

The yields, $\mathrm{mp}$, and elemental analytical data of the synthesized monomers are give in Table I.

\section{Polymerization}

The polymerizations of the synthesized monomers were carried out using azobisisobutyronitrile (AIBN) as an initiator in DMSO, DMAc, or benzene at $60^{\circ} \mathrm{C}$. Monomer and AIBN concentrations were $0.15-0.40 \mathrm{moll}^{-1}$ and $1.4 \mathrm{mmoll}^{-1}$, respectively. The required volumes of monomers and AIBN solutions were charged into polymerization tubes, followed by degassing via three alternate freeze-pump-thaw cycles. After sealing, the tubes were placed in a constant temperature bath for specified times. After removal from the bath, the polymers were precipitated in excess methanol, filtered, dried in vacuo, and weighed.

\section{RESULTS AND DISCUSSION}

\section{Synthesis of Monomers}

Previously, 2-amino-4-( $N$-alkylanilino)-6- isopropenyl-1,3,5-triazines were prepared by two pathway. One is the reaction of 1-alkyl-1phenylbiguanides, prepared from $\mathrm{N}$-alkylanilines, with methacryloyl chloride (eq 1). ${ }^{17,18}$ Another is the reaction of phenylbiguanide with ethyl iodide, followed by the treatment with methacryloyl chloride (eq 2). ${ }^{19}$ However, these methods were limited to below 4 carbon numbers for alkyl group. In order to introduce longer alkyl groups, we investigated here the reactions of AAIT with alkyl halides in the presence of sodium hydride.

The reaction of AAIT with ethyl iodide was followed by the NMR spectroscopy as a model reaction (Figure 1). When AAIT was treated with an equimolar amount of sodium hydride in DMSO- $d_{6}$, the spectrum of AAIT was changed significantly. The signal of imino proton on anilino group of AAIT at $9.32 \mathrm{ppm}$ was disappeared, and the chemical shift of phenyl protons was displaced to higher field. The changes in the chemical shifts of phenyl protons were $0.21,0.15$, and $0.33 \mathrm{ppm}$ for the ortho-, meta-, and para- hydrogens, respectively. Ide et al. ${ }^{20}$ compared the ${ }^{1} \mathrm{H}$ NMR chemical shifts of aniline derivatives with

$$
\text { (O) }
$$




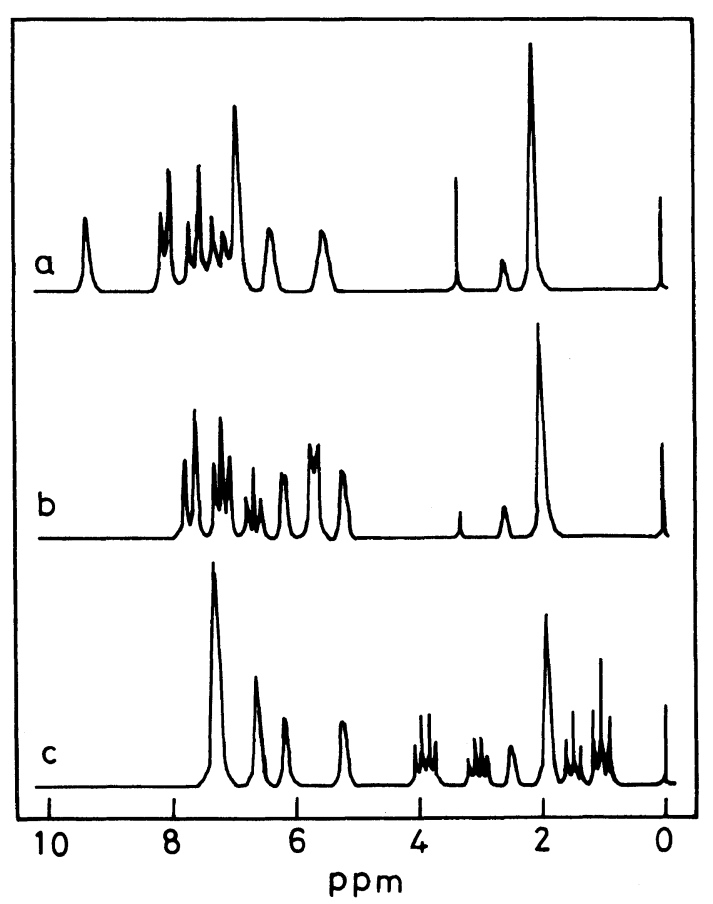

Figure 1. ${ }^{1} \mathrm{H}$ NMR spectra of (a) AAIT in DMSO- $d_{6}$, (b) AAIT in NaH-DMSO- $d_{6}$ solution, and (c) after the addition of excess ethyl iodide to (b).

those of corresponding anilide anions, and found that the change in the chemical shift for para-hydrogen was greater than those for ortho-, and meta-hydrogens. A similar behavior in the chemical shift of phenyl protons was observed in this study. Therefore, it was thought that anilide anion was produced readily by the abstraction of proton from anilino group of AAIT by the treatment with sodium hydride in DMSO. The NMR spectrum after addition of excess ethyl iodide into a solution of anilide anion was shown in Figure 1(c). The spectrum agreed completely with 2-amino-4-( $N$-ethylanilino)-6-isopropenyl1,3,5-triazine reported previously, ${ }^{18}$ except for the signals based on excess ethyl iodide $(\delta 1.77$ and $3.24 \mathrm{ppm})$. Signals of ethyl protons attached to amino group could not be observed. It can be considered that the stability of amide anion of amino group is lower than anilide anion. These results indicate that the
$\mathrm{N}$-alkylation to anilino group of AAIT occurs selectively through the anilide anion (eq 3).

According to the above information, 2amino-4-( $N$-alkylanilino)-6-isopropenyl-1,3,5triazines were synthesized from the reactions of AAIT with nine alkyl bromides, such as propyl, hexyl, octyl, decyl, dodecyl, tetradecyl, hexadecyl, octadecyl, and docosyl bromides, in DMSO in the presence of sodium hydride. The abbreviation of the monomers and the results of the synthesis are shown in Table I. The structures of the monomers were confirmed by IR, NMR, and elemental analysis. These monomers were obtained almost quantitatively without side reactions.

\section{Polymerization}

The results of the polymerization are shown in Table II. Because of the solubilities of monomers, the polymerization were carried out in DMSO for N3, N6, N8, N10, and N12, in DMAc for N12, N14, N16, and N18, and in benzene for N22, respectively. All monomers could be polymerized and white solid polymers were obtained. The polymerization yields and the molecular weight of the polymers were decreased by changing of polymerization solvent from DMSO to DMAc. However, they were not influenced by the length of alkyl group of the monomers in the same solvent.

The $T_{\mathrm{g}}$ of the polymers are plotted in Figure 2 against the carbon numbers of the alkyl side-chains for the polymers. Figure 2 includes the previous data for poly(AAIT) $\left(T_{\mathrm{g}}=230\right.$ $\left.{ }^{\circ} \mathrm{C}\right),{ }^{21}$ 2-amino-4-( $N$-methylanilino)-6-isopropenyl-1,3,5-triazine $(\mathrm{N} 1)$ homopolymer $\left(T_{\mathrm{g}}=\right.$ $\left.202^{\circ} \mathrm{C}\right),{ }^{22} \operatorname{poly}(\mathrm{N} 2)\left(T_{\mathrm{g}}=222^{\circ} \mathrm{C}\right),{ }^{18}$ and 2 amino-4-( $N$-butylanilino)-6-isopropenyl-1,3,5triazine (N4) homopolymer $\left(T_{\mathrm{g}}=196^{\circ} \mathrm{C}\right){ }^{22}$ The $T_{\mathrm{g}}$ of the polymers decreases with increasing the carbon numbers of the alkyl side-chains. This result might be due to the decrease in intermolecular interaction of the polymer such as hydrogen bonding with the increasing carbon numbers of the alkyl groups. 
Table II. Polymerization of isopropenyl-1,3,5-triazines ${ }^{\mathrm{a}}$

\begin{tabular}{|c|c|c|c|c|c|c|c|c|}
\hline \multirow{2}{*}{ Monomer } & \multirow{2}{*}{ Solvent $^{b}$} & \multirow{2}{*}{$\frac{\text { Time }}{h}$} & \multirow{2}{*}{$\frac{\text { Yield }}{\%}$} & \multirow{2}{*}{$\frac{T_{\mathrm{g}}^{\mathrm{c}}}{{ }^{\circ} \mathrm{C}}$} & \multirow{2}{*}{$\frac{\eta_{\mathrm{sp}} / c^{\mathrm{d}}}{\mathrm{dlg} \mathrm{g}^{-1}}$} & \multirow{2}{*}{$\frac{\bar{M}_{w}{ }^{\mathrm{e}}}{\times 10^{-4}}$} & \multirow{2}{*}{$\frac{\bar{M}_{n}^{\mathrm{e}}}{\times 10^{-4}}$} & \multirow{2}{*}{$\frac{\bar{M}_{w}}{\bar{M}_{n}}$} \\
\hline & & & & & & & & \\
\hline N3 & DMSO & 5 & 50.7 & 207 & $0.81^{\mathrm{f}}$ & & & \\
\hline N6 & DMSO & 5 & 57.3 & 171 & 0.53 & 27.4 & 12.8 & 2.15 \\
\hline N8 & DMSO & 5 & 49.7 & 150 & 0.38 & 22.2 & 11.7 & 1.90 \\
\hline N10 & DMSO & 5 & 33.2 & 144 & 0.38 & 13.0 & 5.5 & 2.36 \\
\hline N12 & DMSO & 5 & 51.8 & 142 & 0.94 & 23.6 & 9.3 & 2.53 \\
\hline N12 & DMAc & 8 & 16.4 & 140 & 0.20 & 3.6 & 1.3 & 2.83 \\
\hline N14 & DMAc & 8 & 16.9 & 140 & 0.18 & 7.6 & 3.3 & 2.31 \\
\hline N16 & DMAc & 8 & 14.7 & 136 & 0.19 & 6.3 & 4.0 & 1.56 \\
\hline N18 & DMAc & 8 & 19.6 & 132 & 0.15 & 6.7 & 4.4 & 1.50 \\
\hline N22 & benzene & 3 & 8.2 & 122 & 2.14 & 19.1 & 7.1 & 2.69 \\
\hline
\end{tabular}

${ }^{a}$ Polymerization condition; $[\mathrm{M}]_{0}=0.4 \mathrm{moll}^{-1}$ for N3-N18, $[\mathrm{M}]_{0}=0.15 \mathrm{moll}^{-1}$ for N22, $[\mathrm{AIBN}]=1.4 \mathrm{mmol1}^{-1}$, at $60^{\circ} \mathrm{C}$.

b DMSO, dimethyl sulfoxide; DMAc, $N, N$-dimethylacetamide.

c Measured by DSC at a heating rate of $20^{\circ} \mathrm{Cmin}^{-1}$.

d $c=0.2 \mathrm{~g} \mathrm{dl}^{-1}$ at $30^{\circ} \mathrm{C}$ in tetrahydrofuran.

e Determined by GPC.

f $c=0.2 \mathrm{~g} \mathrm{dl}^{-1}$ at $30^{\circ} \mathrm{C}$ in DMSO.

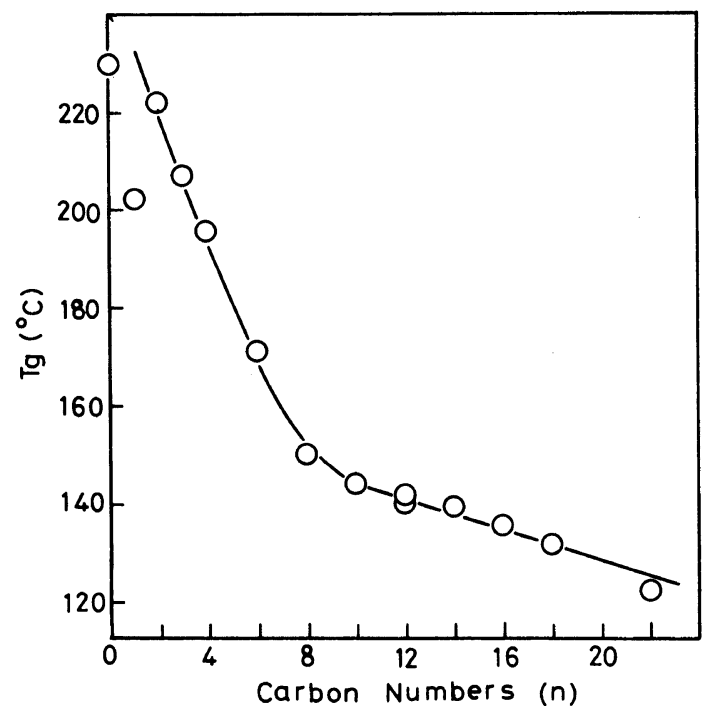

Figure 2. The relationship between $T_{\mathrm{g}}$ of polymers and the carbon numbers of the alkyl side-chains $(n)$.

\section{Crystallization of Alkyl Side-Chains}

The crystallization behavior of alkyl sidechains for the resulting comb-like polymers are investigated by DSC measurement. The polymer sample was first heated from $-100^{\circ} \mathrm{C}$ to $+100^{\circ} \mathrm{C}$, then cooled to $-100^{\circ} \mathrm{C}$, and again heated to $+100^{\circ} \mathrm{C}$. For the polymers having alkyl side-chains up to 12 carbon numbers, no peaks were observed in this temperature region. On the other hand, endothermic and exothermic peaks were observed in DSC curves for the polymers containing above 14 carbon numbers of alkyl side-chains. DSC curves of poly(N14), poly(N16), poly(N18), and poly(N22) are shown in Figure 3 . On the basis of extensive studies on conventional comb-like polymers, ${ }^{23}$ the endothermic peaks observed on the heating processes should be ascribed to the melting of crystallized alkyl side-chains, and the exothermic peaks on the cooling processes should be ascribed to the crystallization of alkyl sidechains.

The transition temperatures determined from the peak tops in DSC curves are shown in Table III, which give the melting point on first heating process $T_{\mathrm{m}_{1}}$, crystallization temperature $T_{\mathrm{cr}}$, and melting point on second heating process $T_{\mathrm{m}_{2}}$. Table III also shows the heat of fusion on first heating process $\Delta H_{\mathrm{m}_{1}}$, heat of crystallization $\Delta H_{\mathrm{cr}}$, and heat of fusion 
Table III. Thermodynamics parameters of poly(N14), poly(N16), poly(N18), and poly(N22) determined by DSC.

\begin{tabular}{|c|c|c|c|c|c|c|c|}
\hline \multirow{2}{*}{ Polymer } & \multicolumn{3}{|c|}{$\begin{array}{l}\text { Transition temperature } \\
{ }^{\circ} \mathrm{C}\end{array}$} & \multicolumn{3}{|c|}{$\begin{array}{l}\text { Heat of transition } \\
\text { kcal unit }^{-1} \mathrm{~mol}^{-1}\end{array}$} & \multirow{2}{*}{$N_{\mathrm{cr}}^{\mathrm{a}}$} \\
\hline & $T_{\mathrm{m}_{1}}$ & $T_{\mathrm{cr}}$ & $T_{\mathrm{m}_{2}}$ & $\Delta H_{\mathrm{m}_{1}}$ & $-\Delta H_{\mathrm{cr}}$ & $\Delta H_{\mathrm{m}_{2}}$ & \\
\hline $\operatorname{poly}(\mathrm{N} 14)$ & -25 & -48 & -34 & 0.25 & 0.27 & 0.23 & 0.3 \\
\hline poly(N16) & -29 & -44 & -29 & 0.65 & 0.58 & 0.61 & 0.8 \\
\hline poly(N18) & -14 & -24 & -15 & 0.98 & 1.43 & 1.44 & 2.0 \\
\hline poly(N22) & 10,38 & 4 & 8 & 3.43 & 3.19 & 3.20 & 4.4 \\
\hline
\end{tabular}

a Number of crystallizing $\mathrm{CH}_{2}$ groups calculated from $\Delta H_{\mathrm{m}_{2}}$.

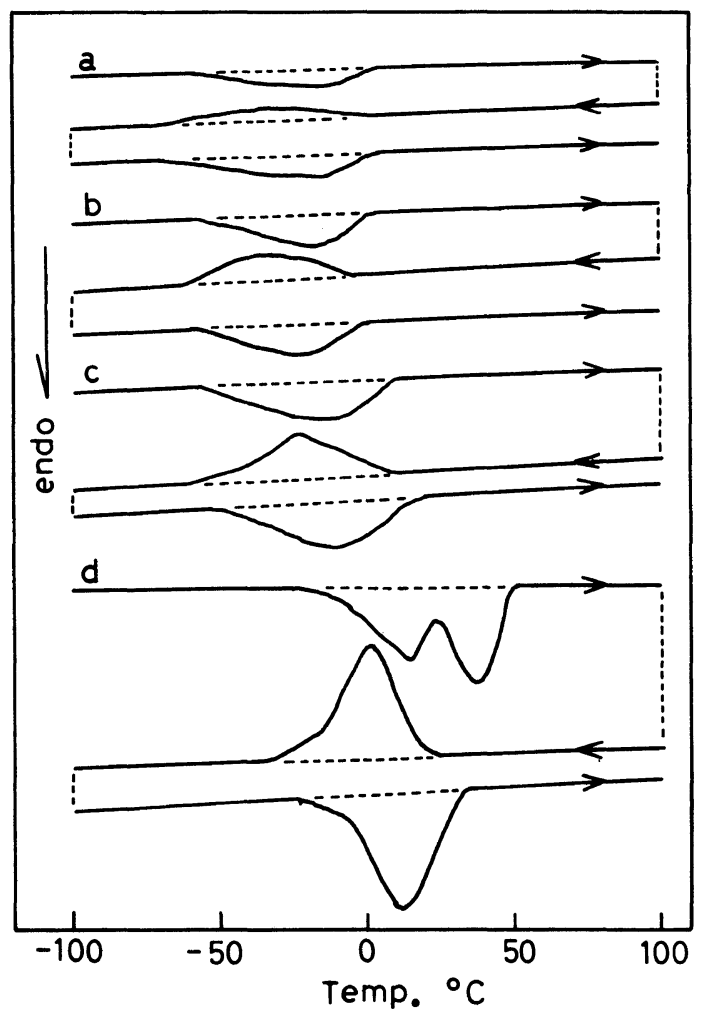

Figure 3. DSC curves of (a) poly(N14), (b) poly(N16), (c) poly(N18), and (d) poly(N22) at the scanning rate of $10^{\circ} \mathrm{C} \min ^{-1}$.

on second heating process $\Delta H_{\mathrm{m}_{2}}$, which were estimated from the DSC peak areas. The transition temperatures and the heats of transition increase with increasing the carbon numbers of alkyl side-chains for the polymers.
This indicates that the crystallinity and the perfection of the crystals are dependent on the side-chain length. This is a general trend for comb-like polymers. ${ }^{23}$ Poly(N22) shows two endothermic peaks on the first heating process at $10^{\circ} \mathrm{C}$ and $38^{\circ} \mathrm{C}$, respectively. A endothermic peak at $38^{\circ} \mathrm{C}$ is probably due to the melting of crystal which formed on standing at room temperature after the polymerization, whereas a endothermic peak at $10^{\circ} \mathrm{C}$ is attributed to the melting of the crystal formed during the cooling from room temperature to $-100^{\circ} \mathrm{C}$ before the DSC measurement.

It is well known that the alkyl side-chains of conventional comb-like polymers crystallize in hexagonal form. ${ }^{23}$ The IR spectra of the present polymers showed a single absorption peak at $725 \mathrm{~cm}^{-1}$, corresponding to the $\mathrm{C}-\mathrm{H}$ vibrations of the methylene chain, which indicate that the alkyl side-chains of the polymers crystallized in hexagonal form. Therefore, the numbers of crystallizing $\mathrm{CH}_{2}$ groups $\left(N_{\mathrm{cr}}\right)$ were calculated from $\Delta H_{\mathrm{m}_{2}}$ on the basis of the heat of fusion of $n$-alkanes in the hexagonal packing $\left(735 \mathrm{cal} \mathrm{CH}_{2}^{-1} \mathrm{~mol}^{-125}\right)$. Because the values of $\Delta H_{\mathrm{m}_{2}}$ have same thermal history in the DSC measurement, the $N_{\mathrm{cr}}$ numbers were evaluated by the use of the $\Delta H_{m_{2}}$. As shown in Table III, the heat of fusion on second heating is almost the same as the heat of crystallization on cooling. The $N_{\mathrm{cr}}$ numbers are shown in Table III. $N_{\text {cr }}$ numbers of conventional comb-like polymers are 9.4 for 
poly(octadecyl acrylate), 14.2 for poly(docosyl acrylate), 5.7 for poly ( $N$-octadecyl acrylamide), and 10.9 for $\operatorname{poly}(N$-docosyl acrylamide), respectively. ${ }^{25}$ The present polymers give smaller $N_{\mathrm{cr}}$ than that of conventional comb-like polymers as shown in Table III. The melting point of the present polymers are also lower than that of the conventional polymers which are $56^{\circ} \mathrm{C}$ for poly(octadecyl acrylate), $40^{\circ} \mathrm{C}$ for poly(octadecyl methacrylate), and $48^{\circ} \mathrm{C}$ for poly( $N$-octadecyl acrylamide), respectively. ${ }^{25}$ These results indicate the low crystallinity of the present polymers compared with the conventional comb-like polymers. Hirabayashi et al. ${ }^{26}$ reported that the crystallization of alkyl side-chains is influenced by the flexibility of the polymer main-chain and that the less flexible main-chain would be unfavorable to the side-chain crystallization. The glass transition of the convensional comb-like polymers were observed at the melting point of the side-chains crystal. Therefore, the main-chain would be flexible enough to allow the side-chain packing. On the other hand, $T_{\mathrm{g}} \mathrm{s}$ of the present polymers are higher than the melting points of the side-chains, and the side-chains crystallized below the $T_{\mathrm{g}}$ of the main-chain. Consequently, the less flexible main-chain of the present polymers would prevent the side-chains crystallization and would give the smaller $N_{\mathrm{cr}}$ numbers.

\section{REFERENCES}

1. C. E. Rehberg and C. H. Fisher, J. Am. Chem. Soc., 66, 1203 (1944).

2. H. S. Kaufman, A. Sasher, T. Alfrey, and J. Fankuchen, J. Am. Chem. Soc., 70, 3147 (1948).

3. R. H. Wiley and G. M. Braner, J. Poly. Sci., 3, 647 (1948).
4. S. S. Rogers and L. Mandelkern, J. Phys. Chem., 61, 985 (1957).

5. C. G. Overberger, C. Frazier, J. Mandehman, and H. F. Smith, J. Am. Chem. Soc., 75, 3326 (1953).

6. J. Lal and G. S. Trick, J. Polym. Sci., A, 2, 4559 (1964).

7. J. M. Barrales-Rieenda, J. G. Ramos, and M. S. Chaves, Br. Polym. J., 6 (March, 1977).

8. J. M. G. Cowie, S. A. E. Henshall, I. J. Mcewen, and J. Veličković, Polymer, 18, 612 (1977).

9. E. F. Jordan, Jr., G. R. Riser, B. Artymyshyn, W. E. Parker, J. W. Pensabene, and A. N. Wrigley, J. Appl. Polym. Sci., 13, 1777 (1969).

10. K. Yokota, T. Kougo, and T. Hirabayashi, Polym. J., 15, 891 (1983).

11. K. Yokota and T. Hirabayashi, Polym. J., 17, 991 (1985).

12. K. Yokota and T. Hirabayashi, Polym. J., 18, 177 (1986).

13. T. Hirabayashi, K. Kasabou, and K. Yokota, Polym. J., 20, 911 (1988).

14. T. Miyashita, H. Yoshida, T. Murakata, and M. Matsuda, Polymer, 28, 311 (1987).

15. M. Takayanagi and T. Katayose, J. Polym. Sci., Polym. Chem. Ed., 19, 1133 (1981).

16. M. Takayanagi and T. Katayose, J. Appl. Polym. Sci., 29, 141 (1984).

17. Y. Yuki, T. Kakurai, and T. Noguchi, Bull. Chem. Soc. Jpn., 43, 2123 (1970).

18. Y. Yuki, H. Kunisada, J. Taniuchi, and N. Takizuka, Nippon Kagaku Kaishi, 224 (1987).

19. H. Kunisada, Y. Yuki, and H. Arai, Nippon Kagaku Kaishi, 97 (1989).

20. S. Ide, K. Iwasawa, A. Yoshino, T. Yoshida, and K. Takahashi, Magn. Reson. Chem., 25, 675 (1987).

21. Y. Yuki, H. Mushika, and T. Kito, Kobunshi Ronbunshu, 36, 385 (1979).

22. Y. Yuki and T. Oouchi, Kobunshi Ronbunshu, 32, 97 (1975).

23. N. A. Platé and V. P. Shibaev, J. Polym. Sci., Macromol. Rev., 8, 117 (1974).

24. D. Chapman, J. Chem. Soc., 4489 (1957).

25. E. F. Jordan, Jr., D. W. Feldeisen, and A. N. Wrigley, J. Polym. Sci. A-1, 9, 1835 (1971).

26. T. Hirabayashi, T. Kikuta, K. Kasabou, and K. Yokota, Polym. J., 20, 693 (1988). 